Industries that all expenditure on research and development should be chargeable against revenue, either immediately or over the commercial life of any asset created. It also urges that the cost of pilot plant, as well as of laboratory buildings and equipment, should be chargeable against revenue.

The London Chamber of Commerce is impressed with the need for attracting to a scientific career a larger percentage than at present of men with firstclass brains, and urges the up-grading of salaries offered to scientific men in industry, the research associations and the universities. Reference is also made to the importance of technical education and of much more generous endowment of the technical colleges; while finally, the importance of publicity is stressed. Individual undertakings must be made more research conscious, including employers, shareholders and workers alike. The report expresses the belief that there are resources of inventiveness and ingenuity among the people of Great Britain generally which skilful propaganda could assist in tapping.

In the main, the London Chamber of Commerce has merely restated the arguments for the expansion of our research effort on lines urged by the Federation of British Industries, the Parliamentary and Scientific Committee, and other bodies and individuals, with the specific exception of its proposal for a central research board. On this proposal two main comments may be made : first, the organization indicated may prove too rigid and demand too much of the individuals constituting the board, which scarcely seems to fit the machinery of government; and secondly, there is no apparent provision for seeing that research is prosecuted in the biological and social sciences in comparison with the physical sciences to the extent required to maintain a better balance in the advancing front of science. That there is need of some further measure of co-ordination of our research effort is scarcely questioned; but the manner in which that can best be planned or controlled without detriment to the internal discipline or freedom of science is a matter for serious discussion.

Here the report does well to raise the question of the adequacy of the University Grants Committee in regard to research purposes, as was done in the report of the Parliamentary and Scientific Committee. The question is also discussed in a recent memorandum on "The Development of Science" issued by the Association of Scientific Workers, which suggests that to assure adequate financial resources for fundamental scientific research and the wise use of those increased resources, a university council, reporting, for example, to the Lord President of the Council, like the Scientific Advisory Committee, should be formed to extend the functions of the University Grants Committee. It should be competent to discuss in detail all questions of university policy, and, without impairing the independence of the individual universities, it would provide a democratic machinery by which the universities as a whole could take the guidance of their future into their own hands, and the Association suggests that a body of the type indicated in the memorandum should achieve a greatly increased measure of self-government of university science by university men of science.

By and large, the stimulation and endowment of fundamental research on an adequate scale is the first and main problem. Opinion may well be reserved as to how far, or how soon, the creation of a university council of the type suggested is likely to proceed without some external stimulus or some far-reaching university reforms; and if university co-operation has not been particularly marked in the past, the capacity of scientific workers to co-operate even within a limited field of science has not been so successful that the prospect of increased self-government will make any pronounced appeal to them or to the community. The first step may well have to be taken by the Government, following the lead given by some such body as the Parliamentary and Scientific Committee. The adequate endowment and prosecution of industrial research should follow from such steps, once fundamental research has been adequately planned and endowed, and given right relations between the State and industry. The discussions which are already proceeding as to the mechanism of State control, the relations between enterprise and planning, between taxation policy and the encouragement of development and research, and between patent law and industrial research are all to be welcomed as contributing to this end. If such discussions can be kept clear of faction or prejudice, and pressed home to lay bare the fundamental issues, they can do much to indicate the right lines on which the organization of research should proceed in Great Britain. They will suggest conditions likely to stimulate creative thought and invention, and also ensure, not merely that the maximum social use is made of advancing scientific knowledge, but also that adequate effort is concentrated in those fields where social needs, instead of financial or other sectional interests, show it is likely to yield the maximum advantage to the community.

\section{WORK OF IMPERIAL CHEMICAL INDUSTRIES, LTD.}

\footnotetext{
$T$ HE record of British industrial achievement during the War remains to be written. A veil of secrecy conceals most of it, and it is only here and there and at rare intervals that a small part of the veil is lifted. Such an occasion was Lord McGowan's speech at the Glasgow Chamber of Commerce recently, when, for the first time during the War, he recorded some of the work of Imperial Chemical Industries, Ltd., emphasizing the fact that it was only a small part of the company's activities of which he could speak. The system of private enterprise on which he said Britain's national greatness had so largely been built had been criticized and misrepresented, and it was the duty of British industry to answer vague innuendo with definite fact and record of real achievement. Especially was it a duty owed to the workers and management class who, so far as
} 
his own companies were concerned, had worked faithfully through more than four years of strain and stress, to deliver the goods both to the fighters in the field and to the people at home.

Though designedly limited in scope, the record was impressive, an outstanding feature being the company's pioneer work in the production of oil from coal, a triumph of courage, foresight, research and engineering skill, none of which, said Lord McGowan, would have been forthcoming in adequate degree unless private enterprise had been free to run the risks involved. No State department could have taken such a decision, involving expenditure of millions sterling; and if it had, Parliament would have vetoed the project. As a matter of fact, the decision

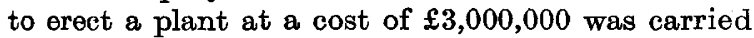
in the face of strong opposition in Parliament and in the Press. Lord McGowan said :

"I.C.I. were then accused of gambling with shareholders' money and wasting money and energy by making something which could be brought from overseas much more cheaply. What has happened? Before the War that plant gave much new employment at a time when unemployment was rife. It used British coal to make motor spirit instead of this being imported. Its operation afforded technical experience which was very valuable when applied to other products. From the national aspect it was vital."

All this and much else has been more than confirmed during the War. I.C.I. and companies like it have, moreover, formed the only source from which men with experience of large-scale operations could be drawn as key men to operate the vast ministries established for war purposes. In numerous other fields besides the manufacture of oil from coal, I.C.I. has done invaluable work, most of which is based mainly on peace-time research carried out by the company.

Lord McGowan said that he had been astonished by the amount of research and invention since 1939 , but most of the results must remain secret for obvious reasons. There is at all events conclusive evidence that the British race has not lost its spirit of inventiveness, and all enemy devices have been more than matched on sea or land or in the air. His company had many inventions which would prove invaluable in peace as in war, such, for example, as synthetic fibres and new kinds of plastics, to say nothing of the many fruits of agricultural research. They were already planning a vast post-war programme which would, among other things, contribute substantially to the provision of full employment envisaged by the Government, and involve an expenditure of many millions of pounds over the next five years for plant replacement, extensions and new factories, including many required for new products. Lord McGowan emphasized that private enterprise is quite capable of showing that spirit of adventure and courage on which the British Empire has been built. His own company, he said, is not peculiar in this: throughaut the whole realm of British industry the same spirit reigns, and only asks for freedom and scope to exercise itself.
The student of political and social science should have much on which to ponder here, though it is difficult in such a case to disentangle political bias from scientific objectivity. The address has been criticized as a record that does not necessarily support the doctrine of private enterprise and as not prese ting a correct picture of the financial support given, and risks incurred, by the State, for example, in the oilfrom-coal enterprise. As a scientific journal we cannot take sides on the political issue; nevertheless, the extent to which scientific research on a large scale has justified itself in this particular example of private enterprise is very impressive. Further; it will be agreed that there appears to be in British industry abundant evidence that the love of adventure and enterprise for its own sake is often as powerful a motive as profit-gaining. It is sometimes complained that we can have no science of society or of politics in the strict sense because $\dot{w} \theta$ cannot have the same exactness of controlled experiment as in chemistry and physics. One is a little weary of this very unhelpful comparison. At all events the student of political science, if we admit the validity of such, can approach these problems in a scientific spirit, collect such experimental data as are available-frequently more abundant than is commonly supposed-and weigh and evaluate motives and causes with an open mind unclouded by political prejudice.

\section{APPLIED CHEMISTRY}

Thorpe's Dictionary of Applied Chemistry By the late Prof. Jocelyn Field Thorpe and Dr. M. A. Whiteley. Fourth edition, revised and enlarged. Vol. 5: Feh-Glass. Pp. Xxiv +610 . 70s. net. An Abridged Index to Volumes 1-5 of the New edition of Thorpe's Dictionary of Applied Chemistry. Pp. 20. 3s. net.

Vol. 6 : Glau.-Inv. ; with an Index to Vols. 1-6, by Dr. J. N. Goldsmith. Pp. xii+611. 80s. net.

(London, New York and Toronto : Longmans, Green and Co., Ltd., 1941, 1943.)

HE troubles of producing such a work as this are manifold even in peace-time. When to war conditions we have to add the death of one of the editors, Sir Jocelyn Thorpe, it is really surprising to see that the standard of contributions in these volumes reaches such a high level. Dr. M. A. Whiteley in a foreword refers to the abridged index to Volumes $1-5$ published at the same time as Volume 5, and indicates by the phrase "had the Dictionary been published as a complete work" that perhaps no more volumes might appear during the War. Since then, an editorial board has been formed comprising Prof. I. M. Heilbron, Dr. H. J. Emeléus, Prof. H. W. Melville and Prof. A. R. Todd. Dr. Whiteley continues as editor and Dr. A. J. E. Welch as assistant editor. It is hoped to complete the current edition with eight further volumes, published at yearly intervals, and Volume 6 is the first of the new series under the editorial board.

It might be thought that the board of editors are better constituted to produce a dictionary of pure chemistry than one dealing with the applied side. This idea is rather emphasized by the articles on heterogeneous reactions and homogeneous catalysis 